\title{
Identifying Total Economic Value of Capilong (Calophyllum inophyllum) in Ternate Island-North Maluku-Indonesia
}

\author{
Mardiyani Sidayat ${ }^{1 *}$ Mila Fatmawati ${ }^{1}$ \\ ${ }^{1}$ Department of Agribusiness, Faculty of Agriculture, Khairun University Jl. Yusuf Abdurahman Kampus Gambesi \\ Ternate 97719, North Maluku, Indonesia \\ *Corresponding Author: dhiany_220973@yahoo.com
}

\begin{abstract}
Beauty leaf tree (Calophyllum inophyllum) or locally called capilong is one of the plants which have big potential to be used for biofuel raw material. Indeed, almost all parts of this plant have high economic potential and are currently being used for important industrial raw materials, such as the cosmetic and the pharmaceutical industry. This study aims to calculate the total economic value of the existing Capilong plants in the Ternate Island by calculating the total economic values which are beneficial to develop as livelihood options for the coastal community in North Maluku. Capilong trees in Ternate Island are distributed in several areas such as Kastela, Rua, Ave-Tacoma, and Takome Villages with a total population of 1002 trees. The result shows that the total economic value of Capilong trees in Ternate island is about Rp $44,244,923,500$ per year. This value is obtained from the sum of the direct use value Rp. 26,324,293,500 per year from the utilization of leaves, fruit, and woods. Indirect value is taken from the replacement cost for embankment construction that calculated Rp 17,920,000,000 per year. While the option value is Rp 463,155 per year and the existence value is categorized zero as seen in the field that the local inhabitants have no willingness to pay because Capilong are growing in the communal lands and they are becoming communal properties.
\end{abstract}

Keywords: Capilong, Total economic value.

\section{INTRODUCTION}

As stated in National energy Policy No 5/2006 that Indonesia should provide national biofuel production (about 5\%) from the total national needs. It also requested the forestry ministry to supply raw materials for biofuel needs, which also includes the granting of forest land use permits, especially for marginal lands [1].

Beauty leaf tree (Calophyllum inophyllum) or locally called capilong is one of the plants which have big potential to be used for biofuel raw material due to its potency on having highest rendement between $37-58 \%$ compared to other plants [2].

Capilong is one of the coastal vegetation that grows along the coastline in most islands of Indonesia, including North Maluku. This plant has great potential to process as biodiesel feedstock because of its high seed oil content [3] and its ability to produce the highest quantities of fruits. It is a very important source of non edible and non-food competing oil for producing biodiesel, it is able to grow in a wide range of climatic conditions, easy cultivation, and high fruit production rate[4]. Capilong is easily regenerated and it also has a high ability to survive with marginal soil conditions which include salt-affected, waterlogged, eroded, and infertile soils [5]. However, it has not been extensively cultivated yet by the people [3], They mostly only grow naturally along the coastline.

In North Maluku, the majority of coastal communities recognized this plant as coastal vegetation that has functioned as the windbreak or for protection from coastal erosion. Culturally, local people used Capilong leaves to treat eye inflammation, dried fruits are being used for handicraft and the wood is valued for the wooden fishing boat construction. Indeed, almost all parts of this plant have high economic potential and have 
been used for important industrial raw materials such as the cosmetic and pharmaceutical industries.

Based on the various economic potentials of the Capilong as mentioned above, this research was carried out to calculate the total economic value of the existing Capilong plants in the Ternate Island by calculating the value of the product produced and its environmental services which are beneficial to develop later on as livelihoods option for the coastal community in North Maluku. In addition, this study also can be used to set up a community development program that enables contributing to economic sustainable development.

\section{METHODOLOGY}

The study has taken place in Ternate Island. Sampling chosen is using purposive sampling method, in the villages of Kastela, Rua, Ave-Taduma, and Takome. This research is descriptive quantitative and qualitative, where the data taken is from field observation and direct interviews with local coastal communities as well as the oil and soap producers who produce their products from capilong. Data on total economic values is taken based on the formula as follow:

Total Economic Values $=\mathrm{DUV}+\mathrm{IUV}+\mathrm{OV}+\mathrm{EV}$

DUV: Direct use value

IUV: Indirect use value

OV: option value

EV: Existence value

\section{RESULT AND DISCUSSION}

\subsection{Respondent Profile}

The total numbers of respondents are 30 persons. Respondent age classification was ranging between 25 55 years old $(76 \%)$ and followed by $>55$ years old $(24$ $\%)$. The majority of them have completed senior high school (80\%), $36 \%, 6,66 \%$ completed College and the rest $(13,33 \%)$ only completed primary school.

\subsection{Identifying the benefit and potency of Capilong in Ternate Island}

As found in the field, the local community utilizing capilong only limited to the use of its leaves for eye inflammation treatment and its woods used for raw material of wooden fishing boat. Currently, some small people utilizing its seeds for processing into crude oil that can be sold for medicinal oil as well as used for soap production. The secondary products which will be potential to develop in the future are including biofertilizers, biokerosene that can be used for cooking purposes, and also possible to use for fishing boat engines. While for its indirect benefit is mainly focus on its environmental service where capilong can be used for coastal protection to minimize the effect of coastal erosion and also being the windbreak. Another beneficial can also possibly carry out is to integrating with ecotourism program because most of the coastlines areas in North Maluku are potential for marine echo-tourism.

\subsection{Analyzing of the capilong product and its environmental service}

Capilong trees in Ternate Island are distributed in several areas such as Kastela, Rua, Ave-Taduma, and Takome with total population of 1002 trees [6].

\subsubsection{Direct Use Value}

The direct use value is including all the benefits that are directly taken from the capilong tree [7]. The calculation of the capilong direct values is presented in the table below:

Table 1 Direct use value of Capilong

\begin{tabular}{|c|c|c|c|c|}
\hline No. & $\begin{array}{l}\text { Direct use } \\
\text { value }\end{array}$ & Number & Rp per year & $\%$ \\
\hline 1 & Leaves & & & \\
\hline \multirow[t]{6}{*}{2} & Fruit & $\begin{array}{l}20.000 . \\
\text { fruit/tree/year }\end{array}$ & & \\
\hline & Oil & $\begin{array}{l}16.67 \\
\text { litre/tree/year }\end{array}$ & & \\
\hline & $\begin{array}{l}\text { Medicinal } \\
\text { oil }\end{array}$ & $\begin{array}{l}66.670 \mathrm{ml}(\mathrm{a} . \\
25 \mathrm{ml} / \text { bottle })\end{array}$ & $1,666,750$ & 6.34 \\
\hline & Soap & 667 fruit & $23,345,000$ & 88.85 \\
\hline & Biokerosene & $\begin{array}{l}15.07 \\
\text { liter/year }\end{array}$ & 60,000 & 0.22 \\
\hline & Bio-fertilizer & $50 \mathrm{~kg} /$ year & 250,000 & 0.95 \\
\hline 3 & Trunk & 30 pieces & $1,200,000$ & 4.56 \\
\hline \multicolumn{2}{|c|}{ Total Per tree/year } & & $26,271,750$ & 100 \\
\hline \multicolumn{2}{|c|}{ Total Population } & 1002 trees & $26,324,293,500$ & \\
\hline
\end{tabular}

Source : Primary data, 2019

The direct use value sourced from capilong leaves cannot be calculated correctly because the use of its leaves is uncertain. While the fruits produced by capilong trees are about 10,000 fruits per tree with a harvest period of two times per year[9]. 1 kilogram contains 400 dry fruits [6]. One Capilong tree can produce $25 \mathrm{~kg} .3 \mathrm{~kg}$ of its dried fruits can result in one liter of crude oil [6], So the total oil taken from one tree in one year is about 66.67 liter.

In Ternate island, capilong medicinal oil for external medicine is sold in packs of $25 \mathrm{ml}$ per bottle with a selling price of RP 25,000 . One capilong tree can produce 66,670 bottles (in packs of $25 \mathrm{ml}$ ), where the yield obtained is about $1,666,750$ /year. While, for soap production, the producer used $25 \mathrm{ml}$ of capilong crude oil to produce 10 soap. So, it can be calculated that in one capilong tree can produce 667 soaps per year with a selling price of $\mathrm{Rp} 35,000$, and it gives the biggest 
contribution from the direct use value which is around $88.85 \%$ compared to other products. The calculation for kerosene shows that the total oil production per tree per year is about 66.67 liter that will produce 15.07 liter of biokerosene with the actual selling price is about $\mathrm{Rp}$ $4000 /$ liter, so the direct use value for kerosene is $\mathrm{Rp}$ $60,000 /$ year. Meanwhile, organic fertilizers that are processed from capilong waste can be calculated as 50 $\mathrm{kg} /$ tree/year with a selling price of $\mathrm{Rp} 5000 / \mathrm{kg}$. The direct use value of organic fertilizer in a year is Rp.250,000. For capilong woods, which is only taken from the oldest trees and/or unproductive trees. So for one tree with a diameter of 1.5 meters and a height can reach 20 meters, the number of woods produced is around 30 pieces woods with the selling price Rp. 40,000/piece, the direct use value of the wood obtained is Rp. 1200,000. With a population of 1002 capilong trees, it is calculated that the direct use value is Rp. 26,271,750 per year and the entire direct values of the capilong population are $\mathrm{Rp}$ 26.324.293.500 per year.

\subsubsection{Indirect Use Value}

The calculation of indirect use value from Capilong is presented in the table below:

Table 2 Indirect use value of Capilong

\begin{tabular}{cccc}
\hline No. & $\begin{array}{c}\text { Indirect use } \\
\text { value }\end{array}$ & Number & Rp per year \\
\hline 1 & Embankment & $1.600 \mathrm{M} 3$ & $17,920,000,000$
\end{tabular}

The indirect use value is calculated from the presence of Capilong trees in the coastline that will have a function to protect the coast from coastal erosion. So, it can be said that the replacement cost can be calculated by using the embankment construction cost which is about $\mathrm{Rp}$ $1,400,000 / \mathrm{m}^{3}$ with a height of 1 meter and a width of 80 $\mathrm{cm}$ or 0.8 meters [8]. In total, the location where there are Capilong trees is about 16 kilometers, so that means, it can be calculated $16.000 \mathrm{~m}^{3} \mathrm{x} \mathrm{Rp} 1,400,000$, so the total indirect value is RP 17.920.000.

\subsubsection{Option Value}

The option value is a potential value that can be calculated for the future. The option values of Capilong are estimated using the biodiversity value which is about US\$ 15/hectare/year. According to the Rp exchange rate of Bank Indonesia (December 2019), 1 US\$ is equivalent to $\mathrm{Rp} \mathrm{14.035.} \mathrm{The} \mathrm{total} \mathrm{of} \mathrm{Capilong} \mathrm{areas} \mathrm{is} \mathrm{around} 2.2$ hectares, so the option value calculated is $\mathrm{Rp} 463.155$ per year. It can be explained that the Capilong trees are not cultivated, so it does not have a specified spacing between trees and/or its growth distribution occurs randomly. The option value will increase following the planted areas of Capilong. If the growing capilong areas are extended, then the option values will automatically increase.

\subsubsection{Existence Value}

Existence value is related to the respect of someone toward their natural resources. Based on the field study taken from observation and interviews, the existence value is considered zero because all respondents are categorized as free riders. According to their perception, they have no willingness to pay because Capilong are growing in the communal lands and they are becoming communal properties. The utilization of Capilong for economic benefit is something new for the local inhabitants and/or in other words they are just starting to manage Capilong for a new livelihood option.

\subsection{Total Economic Value Of Capilong In Ternate Island}

The total economic value of Capilong is a compilation of the values taken from the direct use, indirect use, option, and existence values. Total economic values calculated for Capilong is about $\mathrm{Rp}$ $10,530,519,419.00$ per year as presented in the table below.

Table 3 Total Economic value of Capilong

\begin{tabular}{cccc}
\hline $\begin{array}{c}\text { No } \\
\cdot\end{array}$ & Value & Rp per year & $\%$ \\
\hline 1 & Direct use value & $26,324,293,500$ & 59.49 \\
& & & \\
2 & Indirect use value & $17,920,000,000$ & 40.51 \\
3 & Option value & 463.155 & 0.001 \\
4 & Existence value & 0 & 0 \\
\hline & Total Economic Value & $\mathbf{4 4 , \mathbf { 2 4 4 , 9 2 3 , 5 0 0 }}$ & $\mathbf{1 0 0}$ \\
\hline
\end{tabular}

In addition, the result of studies has been discussed with the local authorities such as Local Government and Private sectors. Interestingly, they are responsive and intend to integrate into local development planning in the future. However, as the Covid 19 pandemic outbreak occurred globally, all the initial planning toward this issue were being postponed.

\section{CONCLUSION}

The total economic value of Capilong trees in Ternate island is about $\mathrm{Rp} 44,244,923,500$ per year. This value is obtained from the sum of the direct use value $\mathrm{Rp}$ $26,324,293,500$ per year from the utilization of leaves, fruits, and woods. Indirect value is taken from the replacement cost for embankment construction that calculated Rp 17,920,000,000 per year. Meanwhile the option value is Rp 463,155 per year and the existence 
value is categorized as zero as seen that all the respondents are categorized as free riders that have no willingness to pay due to the fact that Capilong is not cultivated and only naturally growing in the communal lands.

\section{ACKNOWLEDGMENTS}

The author would like to thank LPPM Universitas Khairun for the research fund and the 6th FANRES International conference 2021 committee for holding an international seminar and giving a chance for publication.

\section{REFERENCES}

[1] National Energy Policy. Preidential Regulation No 5/2006.2006

[2] Badan LITBANG Pertanian. Bahan Bakar Nabati. 2013

[3] Fadhlula M.et al. The potential of nyamplung (Calophyllum inophyllum L.) seed oil as biodiesel feedstock: effect of seed moisture content and particle size on oil yield. Energy Procedia 68 ( 2015 ) $177-185$. Elsevier. 2015

[4] Aswath N. et al. Maximizing Energy Recovery from Beauty Leaf Tree (Calophyllum inophyllum L.) Oil Seed Press Cake via Pyrolysis. https://www.mdpi.com/journal/energies. Energies 2021, 14, 2625. https://doi.org/10.3390/en14092625

[5] Westworth. S. et al. Application of FTIR-ATR spectroscopy to detect salinity response in Beauty Leaf Tree (Calophyllum inophyllum L). Energy Procedia 00 (2017) 000-000.Elsevier.2019

[6] AAI Project report.Empowering farmers to utilise Beauty Leaf Tree (BLT) as source of biodiesel energy in Ternate.2019

[7] Alam S et al. Ekonomi Sumberdaya hutan. Buku ajar.2009

[8] Analisa Harga satuan talud. .Dinas Perumahan dan permukiman Provinsi Maluku Utara.2019

[9] Leksono Budi, 2016. Sekilas tentang nyamplung. Balai besar penelitian bioteknologi dan tanaman hutan. Jogjakarta 